\title{
Life stories of elderly women with cervical cancer: a look beyond getting sick
}

\author{
I ${ }^{1}$ Náiade Melo Costa, ${ }^{2}$ Adriana Falangola Benjamin Bezerra, \\ ${ }^{3}$ Keila Silene de Brito e Silva I
}

Abstract: Chronic degenerative illnesses have currently taken on a great predominance at the epidemiological profile, by affecting specially the elderly population. Among such diseases, Cancer has been studied through the broadening of information, which brought scientific advancement for the disease care. However, such topics constantly focus on statistic data, setting the lifetime story of those people aside. This paper aimed at understanding the process of sickness among elderly women and its development up to the diagnostics of uterus cancer through getting closer to their lifetime stories. It is about a qualitative research whose methodology used was that of life history. The methodological choice aimed at providing an intersection in the lives of different women, giving visibility to their memories. Five elderly women between 62 and 89 years old participated in the research, which turns into distinctive lifetime stories, with their singularities, though they interweave before the hard reality faced by them along their aging. Their relationship with their getting-sick development is surrounded by fear into different ways. It is necessary, therefore, to look to the elderly women uniquely, regarding the social relations that interfere during their lives and determine their aging.

> keywords: elderly; woman; uterus cancer diseases.

\author{
${ }^{1}$ Secretaria Estadual de Saúde \\ de Pernambuco. Recife-PE, Brazil \\ (naiademelo@gmail.com). \\ ORCID: 0000-0002-7354-7678 \\ ${ }^{2}$ Medicina Social, Universidade \\ Federal de Pernambuco. Recife-PE, \\ Brazil (afalangola@uol.com.br). \\ ORCID: 0000-0002-5278-3727 \\ ${ }^{3}$ Núcleo de Saúde Coletiva, \\ Universidade Federal de \\ Pernambuco. Vitória de Santo \\ Antão-PE, Brazil (britokeila@ \\ hotmail.com). \\ ORCID: 0000-0002-0291-0708
}

Received: 27/12/2019

Approved: 13/03/2020 Revised: 23/03/2021 


\section{Introduction}

Studies regarding the aging process are often carried out in the light of the epidemiological data, by linking diseases that prevail over the mortality profile to senescence. Notwithstanding their need either to the science development, or the unveiling of reality or to subsiding the elaboration of public policies for the field, they are insufficient to allow a deeper apprehension of reality. It is not common to find researchers who wonder who these elderly really are beyond numerical data whose measurement is incapable of defining an extremely heterogenous group as the Brazilian elderly population. It is even harder to understand such phenomenon when inserting them into this complex society.

From an individual point of view, it is considered an elderly in Brazil one who is from 60 years old onwards. Although old-age is customarily understood as a pinpoint in life, which sets its "natural" process of growth and maturation, we learn aging as a biopsychosocial process where both rhythm, length and effects of physiological senescence report differences according to socioeconomic, psychological and genetic-biological factors, among others (TEIXEIRA, 2008a).

In Brazil, the fast development of this process causes great effects on both public managers and society in terms of organization for the reactions to social needs. We highlight the elderly experienced by the population who have undergone most part of their lives to work force as a means of production, which is experienced as a period of loss, poverty and denial of their rights (HADDAD, 2017; PAIVA 2014; TEIXEIRA, 2008). We agree with Paiva (2014), when he defends that the "tragedy of getting old" is not a natural data in this phase, but the result of objective living conditions of those workers, once that, in their process of aging, the individual is not removed from their history as a social being.

Reflecting on the current aging reality in the country is to do it so by coming the feminine bias out. The aging feminization draws attention, once that in 2000, the average between elderly women and men was $100 / 81$ whereas the projections by 2050 point out the same proportion of women is to be around 76 men (NASRI, 2008).

It is necessary to detach this is not a natural data, result only of the country's populational aging rise. There are different social and cultural factors interfering in this process. However, what we would like to highlight is that elderly women nowadays 
are a concrete result of this social construction, which covers up, especially within the discussion of aging, the real debate on such gender implications for their lives.

Gender is defined as a constitutive element at social relations based on noted differences between the sexes and it is the first stage of life where power speaks out (GOMES et al., 2018, p; 1998). Though a significant debate regarding this dynamic and socio-historical category takes place, there is a movement towards an ideological and conservative perspective of a merely natural distinction between men and women. It is an attempt of disqualifying and concealing this discussion which "relates to the way societies cope with human body perception as well as its consequences and constitutes arrangements that are changeable in the face of new situations created by human practices" (Free translation) (GOMES et al., 2018, p. 1198).

With the rise of private property requiring new configurations in family groups, whether in work relations or in the social organization, new social relationships prevail over the lives of men and women. To women, new tasks, especially the task of procriation, of mothering and wifing under the demands of monogamous marriage, leaving the household space as a summary imposition, while the man was left the work developed out of the domestic space (SANTOS; OLIVEIRA, 2010, p. 13) (Free translation)

Those social relationships set out the unequal way of insertion of women in society. Objectively, it is not granted to women equal access to work and income; education for this public becomes a means of sexism-based relations as well as religion becomes a strong influence on the maintainence of this idealized thought of women reinforcing their reproductive functions and the traditional family model (SANTOS; OLIVEIRA, 2010, p. 13).

This reality is not altered when changing the focus on elderly women. Reflecting on the relationship between gender and aging is to face up two distinctive ways conceiving both feminine experience and growing old (DEBERT, 1994, p. 33).

The process of becoming na adult until seeing oneself as an elderly woman projects an image that tends to hide a long path on coping with different denials of the individual's fundamental rights, including the right to freedom. Despite several social struggles undertaken especially by the feminist movement, which, over the years, reflects both on the feminine gender's social construction and the violations experienced by women, this reality is even more present and cruel to elderly ones. Hegemonically, there is, around their image, an association of the feminine identity to the domestic aspect and to family reproduction (BELO, 2017). In other words, their feminine condition is canceled and it seems pointless 
[...] to ask if women over 60 years old should be regarded as women or just elderly. Nevertheless, on a daily basis, the situations on which this contradiction is based are frequent, as though they were no longer women, but merely old timers. [...] Such ambiguity brings up a prejudice rooted in common sense - but also present in studies about aging as well as in public policies - which accounts only women's needs in their reproductive phase (BELO, 2017, p. 120) (Free translation).

Social relations on which elderly women's social construction is based produce differences that are expressed by several aspects of their lives. We highlight the uneven way in which they are assisted by the state. Regarding health, this fact is clear when realizing most of policies and programs are still aimed at women in their maternal and reproductive phase.

We point out the assistance given to uterus cancer (CC) which, though it is a disease of high power of prevention and cure and slow process of assembling, still keeps high rates of mortality (BRASIL, 2013; INCA, 2011; SANTOS, 2011; SILVA et al., 2014)

Data reveal that, regarding invasive carcicoma, a rise on its incidence takes place from the age of 30, with a new peek at 60 (FLORIANO et al., 2007; INCA, 2001). Silva et al (2014), in a study carried out in a municipality of the state of Sao Paulo, found an insufficient coverage to the Pap smear and focused on younger women, as the more serious diagnostics preponderate on advanced-aged women.

Those results reinforce the research carried out by Albuquerque (2009) and Santos (2011), in the state of Pernambuco, Villa (2009), in the state of Mato Grosso, e Vilaça et al. (2012), in the state of Minas Gerais, where they found out the same tendency. However, only in 2011 the INCA (Cancer National Institute) expanded the priority age group for the tracking of women in risk of developing CC (Cervical Cancer) up to the age of 64 , since it used to be up to the age of 59 .

Specifically about cervical cancer in elderly women, it is noticeable they do not use to be summoned to undergoing the screening exams, the one that prevents the disease. Thus, many of them experience initial factors during a long time and when they are diagnosed, the illness is at an advanced stage. According to Datasus (2012) data, only in 2011, over two thousand elderly women died in Brazil as a result of this kind of cancer.

As seen before, uncountable studies confirm the reality experienced by countless elderly women regarding health care as well as the CC. Yet, these studies do not exceed the epidemiological scope, concealing from their discussions the social 
determinations that directly interfere in the lives of those individuals. That is why the writing of an article was proposed, going further and straight to the elderly women sickening process at follow-up to uterus cancer by understanding their lifetime stories.

\section{Methods}

This work is supported by a qualitative approach, so we agree with Minayo (2002) when concerning about a level of reality which cannot be quantified. It lies upon a universe of meanings, motivations, aspirations, beliefs, values and attitudes which correspond to a deeper space in the relationships.

In a lifetime story approach, we found out a possibility of bringing up different women's experiences, by giving visibility to their memories. The Lifetime Story is seen as a privileged possibility of analysis and interpretation which enables the access to various dimensions that influence at an individual's life (MARANGONI and OLIVEIRA, 2012). As people speak up, we can have access to their experiences, which is only possible indirectly, since they bring out information the way they perceived and interpreted those events for themselves (SILVA; TRENTINI, 2002; ROCHA-COUTINHO, 2006).

The Life History method is a scientific method at all force, validity and credibility of any other method, mainly because it reveals that, as individual as a story is, it is always collective (SILVA et al., 2007, p. 33-34) (Free translation)

The present study was carried out in the Cancer Hospital of Pernambuco (HCPE), which has been a reference in the oncological care for 70 years and responsible for attending over $55 \%$ of the population under neoplasms treatment (HCPE, 2015). The choice of the research's participating subjects was based on the daily analysis of medical records of women over 60 who lived in the state of Pernambuco and were in the follow-up for cervical cancer treatment at the institution.

Having all women residing at different locations in the state, which also includes the Metropolitan region, Zona da Mata and Sertao regions, was a priority. From their agreement, interviews were carried out, on the days they had scheduled appointments, from January to march of 2016. At the end, five elderly women between 62 and 89 years old participated in the study.

It was used a narrative in order to enlarge the possibility of understanding the lives of such women. To Castellanos (2014), through narratives, the individual translates a way of being in the world. In this work, the focus of narratives was the 
life stories of women and not the infirmity itself. The lines of the interviewees were summarized because we highlighted the most important aspects in their lifetime, resulting in individual narratives that, despite presenting some resemblance among them, are unique experiences.

The names used in the results had their anonymity granted. The requirements of the Research Ethics Committees (REC) were fulfilled, and the work was submitted and approved by the Federal University of Pernambuco (UFPE), under the CAAE (certificate of presentation of ethical appreciation) 50815615.0.0000.5208 and the institution where the study was carried out. This research is an integral part of projects financed by the Foundation for the Support of Science and Technology of the State of Pernambuco (FACEPE) and CNPq (National Research Council).

\section{Results}

The life histories obtained in this study are characterized by the individual report of each of the five women who, although they do not know each other, have much more in common than just involvement with CC. The path of these women for health care is full of diverse and diffuse ways, in which the gateway to the health system is mostly configured in high complexity.

The lack of access to the basic right to information is a determining factor in their illness process, since they were unaware of the importance of periodically submitting to the preventive CC screenings, as well as the disease itself. In addition to having many questions and uncertainties about what they would face in their treatments, the diagnosis of cancer turns, for some of them, into a death penalty. Fear becomes an inseparable companion throughout part of the treatment, as well as the constant financial trouble.

These determinations are directly related to the life stories of these women presented below.

\section{Cora (62)}

I live in a farmland [...] 7,5 miles away from downtown [...] My father has never enrolled us in any school, he hasn't never allowed us to study. I've never been to school myself. [...] I have always longed for some education but he was never interested to. He only forced us into laboring at the farm, to plant beans, clean up bush. [...] I worked at the farm all the time, by using the hoe. [...] My life was only that: my house and the farmland and that's it. I worked at the farm and so my husband and children. [...]! I got married at an 
old age. I've never wished to marry. I wish I had lived as a spinster. Because I saw my sisters' suffering. Then I said to myself "who knows if I won't suffer too" [...]. But when I saw him for the first time, I fell in love right away, and married him. I got married at the age of twenty-nine, then I became a mother one year after. I had three children. [...] I've never had a good life, I only worked over and over and looked after my kids. [...] I stopped menstruating five years ago. In 2014, there was a drip. And because of that, I raced off to Petrolina. When arriving there, the doctor did an exam and said I didn't have anything, but It was the disease: the beginning of a cancer. The days were passing by, times were passing by, then after the drip, some blood came out. So I bled for one year. I began the treatment one year ago. I did all the treatment. Now I'm feeling better [...]. I used to do the yearly exam, but I set it aside. After about three and half years... I wondered: I had already done three exams, but then I kept thinking: do I have to take the exam every year?

\section{Dorothy (64)}

I just had a father. My mother had already passed away [...] i was between 10 and 11. I had six children, five siblings [...]. I felt responsible for them, because when we don't have a mother we have to replace one, taking care of the house on behalf of a mother. I kept doing it and so taking care of my family too [...] And studying was not in my mind. I worked in the farm, cleaned up beans, planted potatoes, I spent many years scraping yucca. I liked to live in the woods, working in the farm, cleaning yam, potato, reaping green beans, I really enjoyed that [...]. I didn't get married formally, I went to live with someone. I was over 20 when we went to live together [...]. He used to go out to work, and I stayed home doing the chores, I continued to have more kids, and then I kept looking after them and after a while the marriage didn't work out, so we broke up [...].

He drank a lot [...]. I didn't like when he got violent [...]. I used to work, got some money, paid for a room, did groceries, prepared some food for the kids [...]. After that I found another partner who died [...]. He didn't use to drink, but it was like the first one, kind of problematic. I looked after him, and so our kids and my kids from the first relationship too. Finally, I broke up and I didn't want anoyne else. I had five children from the first marriage and more five from the second one [...]. I didn't want to have a lot of children, but I didn't avoid them, sometimes I didn't talk but I actually didn't know how to avoid them. [...] After I widowed, I started to work for a family as a maid. And then I got another household, did the wash-up, swept the floor. I've never taken the exams all women do, so after a while I began to hurt, over and over, but I believed it was just one more period, then I used to go to the doctor every month but no one said a word. One day, I was at home alone [...] and suddenly I started bleeding a lot."

\section{Simone (65)}

I lost my father when I was 29, I don't have a mother either, also no brothers nor sisters, I have no one else. The only thing I have is the family I got. Husband, kids, grandkids. But no one remained from my first family [...]. My parents had 18 children. But all of 
them died. It was just me. I was the first child and I'm here telling the story. They all died of illness. My mother partied and drank a lot. She was the kind of woman who loved partying, she left all her children sick at home, they threw up a lot. They ate clay, sand. [...] I hit one, hit another, bathed them. There was no bed, we slept on a small mattress. In the morning, we woke up dirty, then we went swimming in the river, got it? So they began to die, one by one. [...] I was the only one who survived because I was raised by my father, because my father had borken up with her, but who really raised me was my stepmother. [...] I've never been to school. My father has never enrolled me. He put me to work. I took lunch to the factory. Took breakfast too. I earned some money, but handed it to my father right away so that he could buy some groceries. [...] I've never studied. Ever. But I longed for that for a long time. I used to drop the kids off the school, stood at the door... I had no condition, you know? [...] it was only work and work. I didn't know I had cancer. I've never had any prevention. Then I kept bleeding for 6 months. [...] So the doctor scheduled an appointment and i went there, It was when I found out I had cancer at an advanced stage.

\section{Chiquinha (77)}

I was raised motherless, she died very young, my dad died at the age of 60 , he left other three kids. I'm the oldest one. Then they all died of heart attack, they just fainted and died suddenly. When my mom died, my grandma started to raise me and when daddy died I was an adult already [...] I was the one who nursed him. [...] I've never been to school because by the time I was raised kids went to school only if their parents paid for it. I stood home struggling, over and over, I learned how to cook, get my food from the farmland, working, cooking again and every now and then chatting with my friends [...]. I got a boyfriend when I was growth. I didn't get married, when I was about to marry him, I wento to bed with him and had my children, [...] I was thirty-five when I gave birth to my youngest. [...] By the time I gave birth to my boys, we didn't use to go to the maternity, we used to give birth indoors with a midwife. [...] I told myself I'd never submit to sterilization nor want to have men any longer, even if he came to me covered in gold. I kept working since my kids were toddlers, I raised all of them myself, I was kind of a self-employed, I worked for all of women, did some stuff to other ones, doing the laundry, reaping beans in the farmland, picking some corn, I did all of that in order to survive. [...] As time passed by, I began to mestruate, then I thought I was going to die because old women getting periods mean to die right away. [...] then I went to the doctor, first I went to Araripina, 'cause I'm poor and penniless, I have nothing, that's why I went to the doctor in this city and there I had to spend money, even what I couldn't afford, then they took some exams, checked up my whole body and then they said: You have a uterine myoma, and it's been a long time you have it, so I replied: and now what? I did a biopsy, it hurt a lot, after fifteen days the results came out. They told me they would send me to the capital city. When arriving here I kept suffering, crying, making a lot of mess [...], I've been undertaking many painful exams but I got better, got better from the pain I was feeling. 


\section{Maria (89)}

I am 89, indeed I am [...] we who are from the countryside start working hardly quite early, at the age of five we start doing the household chores. I began to work at outside at 10 , I worked a lot weeding with a hoe and I even learned how to sew, since I sewed my clothes myself. Dad bought those tiny little hoes and he weed very well [...] That's how the life in the countryside is. [...] I went to school only for one and half year, because dad took me out of it when he realized I had learned how to read. I had a good memory. I learned how to read, how to write, I even wrote letters down [...]. They put me in the school midseptember, from that month I attended classes in october, november, december, and also did the first Communion. I was a teenager, I was 14 . Then, they took me out of school to work on the harvest. I spent several months without going to school. I only returned in January. So, I stood there in january, february and march. After that, I left school to work in the plantation of the farm. Dad digging and me placing the seeds. When I finished planting for all the season, I went back to school. That's the way I attended classes, It didn't last even one year and a half. I learned how to read, and write and count because I had a good memory. I was 14 when my father took me out of school, I didn't return because he didn't allow me to [...] I got married at seventeen, nearly eighteen. [...] I was married to my husband for sixty-five years but he died recently [...] It seems I was a bad person because I got pregnant but lost the babies [...]. Even though, I had eight children. We worked at a small grocery for a long time. So my husband got some extra and went to play the single man. But he didn't know how to use money. Sometimes men don't know how to use it [...]. He started hanging out, then dating other women. My children took more care of the store than him. I also took care of the house. But when one is married, it is the husband who owns everything, who solves everything [...]. He left me his pension. I have this income, because he could never afford my social security but he could afford his. [...] I found out cancer because I went to take the screening exams. [...] cancer was the outcome. But I settled for this illness, you know? I didn't get desperate, thinking I was going to die, thinking there was not a cure. Not me. I went to care and treat my disease.

\section{Discussion}

Learning about the reports on those women's life stories leads us to many reflections. They are stories of survivors of a violent society. Those women, countless times, were disregarded as individuals, as if they only existed to satisfy the most different wishes of parents, companions and the society that previously determine what they can be, what they can want or what they can achieve.

When choosing the use of gender violence modality, it is learned that such violent actions are produced by relational contexts and spaces, and therefore, interpersonal, whose societal and historical scenarios are uniform. The centrality of these violent actions is focused on women, whether physical, sexual, psychological, patrimonial or moral violence, both on private-family scope and work or public environments. It is not about taking a victimizing perspective regarding women, which have received important criticism, but 
highlighting that the expressive concentration of this kind of violence historically lies on feminine bodies and violent relationships exist because the asymmetrical relations of power permeate people's workaday lives (BANDEIRA, 2014, p. 451)

In this perspective, denying these families an access to education reveals in addition to sexism, a concrete life condition, where kids were forced to contribute with their workforce in order to enable their families' survival. It also reinforces the damage caused by the absence of legislation regarding social guarantees, which might improve their lives.

The shortage of research on this matter means that nowadays such social issues were added to the statistics of the group of illiterate elderly in the country. An ethnographic study by Kullok (2012) carried out with elderly women in rural areas, points out that the level of education among them has always been extremely low, for none of them managed to finish the elementary school. Some knew how to write only their name, because, at that time, they learned just enough to sign their marriage papers. Just like in our study, Kullock identified elderly women who expressed the feeling of exclusion, sadness and even revolt at the impossibility of school access. The author also noted that child labor was the norm, both in agricultural activities and in homes.

Peres (2010) emphasizes that, although we now have the Education Program for Youngsters and Adults (EJA), as the only educational alternative for the "out of school age" population, It was not a program designed for the elderly population, considering their particularities, but for the group of adults in general, without differentiation.

Notwithstanding the fact that the family is an important space for social protection, especially after the decrease in the role of the State on granting and defending social rights, it is permeated by a tangle of complexities and is organized according to the reality in which it is inserted and which is historically determined. When analyzing this aspect, from the reports, it is clear that reflecting on these mediations becomes a fundamental exercise.

All women had a relationship with work since childhood, both domestic and in agricultural ones and, even after many years, it was work that provided their survival, as well as that of their families.

The division of labor by gender, which is revealed not only in the job distinctions considering what is for females or males, but also in the hierarchy and inequality in access to the means of production, to work acquisition and to the wealth produced by it. As a result, jobs considered to be male are more valued and better paid, while those considered 
to be female are devalued and some are not even considered work, as is the case of domestic work (CISNE, 2015, p. 140). (Free translation)

Kullock (2012) also observed that it was through pension or retirement some families supported themselves or got some extra family income, whilst they did not find any elderly woman who declared herself head of the family. This data differs from our study, which identified that most elderly women interviewed were responsible for maintaining their families.

Even though women do not directly address issues related to sexuality in their stories, mainly because the topic is still commonly seen as a taboo, we notice strong gender relations that mark their lives. Issues such as marriage and motherhood, although they are a target for controversy about the desire for fulfillment on some of them, occur almost as a natural fact, as if there could be no alternative for them over the course of their lives.

The analysis of sexuality, procreation and motherhood was placed at the center of feminist theory and the history of women. In particular, feminists highlighted and denounced the strategies and violence through which male-centered systems of exploitation attempted to discipline and appropriate the female body, highlighting that women's bodies were the main goals - privileged places for the implementation of power and relations techniques (FEDERICI, 2004, p. 22). (Free translation)

We observed, through those stories, the impossibility of these elderly women, over their lives, to make choices that involved their own body, and this reality remains in this phase of life and now is affected by a morbidity.

In capitalist society, the body is for women what the factory is for male wage workers: the main terrain of their exploitation and resistance, as well as the female body was appropriated by the State and by men, forced to function as a means for the reproduction and accumulation of work. In this sense, the importance that the body acquired, in all its aspects - maternity, childbirth, sexuality, is well deserved, whether on the feminist theory or in the history of women (FEDERICI, 2004, p. 25). (Free translation)

Not least, it is a real taboo to discuss aging and sexuality. Debert and Brigeiro (2012) report that the idea around sexuality emerged as a consensus in the last three decades. But at the end of the twentieth century, more emphasis is placed on the debate around sexuality in old age. One hypothesis is that with the rise in the number of elderly people in the population as a whole, there is a greater interest in the goods and consumption market in transforming the experience in this phase of life (PASSAMANI, 2017). 
However, even in old age, experiences about sexuality happen in different ways on both men and women. Gender relations are closely associated with the way in which sexuality is exercised in a given context. In our society, men and women are socially constructed in various ways. The social representations built in this process come from the way of conceiving societies (HEILBORN, 2006). Studies show that the social construction of these women was surrounded by greater control, which makes the full development of sexuality together at this stage of life (DEBERT; BRIGEIRO, 2012). Whilst the authors argue that old age would be the ideal time for this women liberation, since there is no longer a strong demand for responsibility for children, husbands and home, in addition to their long past life experience.

There is a direct relationship between the sexual life of individuals and the socio-cultural context in which they are inserted. As a result, sexual practices differ depending on the references that guide this social group (HEILBORN, 2006). Although the experience of sexuality for women is full of challenges, especially for elderly women, this is a dimension of life that is experienced by many of them. This has also been an effort practiced by specialists in the field who understand sexuality today as a fundamental issue on active aging (HENNING; DEBERT, 2015; DEBERT; BRIGEIRO, 2012). Gender and sexuality are social determinants of health in connection with others (GOMES et al., 2018).

Sexuality has also a direct link to CC, and hence, it is attributed to prejudice, the lack of information and its view as an asexual being, the fact that this public is not commonly tracked in order to take preventive actions (COSTA et al., 2010).

The stories point to a lack of knowledge about the disease and also the different means for its prevention. A study carried out by Santos et al. (2011), with fifty elderly women who sought spontaneous care at a Family Health Unit (USF) in the state of Piauí, found that the interviewees were aware of cervical cancer and that this knowledge was frequently related to the involvement of the pathology by someone close, or even for having read or heard about it.

Regarding their relationship with Pap tests, we realize that they have yearnings and fears about the exam. Costa et al. (2010) carried out a study with elderly women revealing that, when asked about the Pap smear, $21.7 \%$ of the women revealed they had never done it. They claimed they were not interested in doing so for several reasons: not having an active sex life; fear and shame. They did not find the 
examination important in the face of possibility of death. The survey also found that $63.9 \%$ of the women interviewed did not have regular exams.

Another study by Fernandes et al. (2009) with women aged between 15 and 69 found out that $46.1 \%$ of the interviewees showed adequate knowledge of the exam, with a higher level of education associated with a greater number of knowledges. Among the main obstacles to not performing the exam was shame

Santos et al. (2015), in a study with women between 25 and 64 years old, attended in a medical facility in the capital city of Maceió in the state of Alagoas, concluded that, despite the high number of women found who were undergoing the preventive exam, many were unaware of its real purpose, while others felt ashamed and embarrassed during its performance.

The stories submitted by such women reveal flaws in the public health system when not selecting these women to carry out preventive actions against the disease, not only in their old age, but for their lifetime. Concurrently, it is important to emphasize that their stories show access to both tertiary sector and health care in due time, enabling these women, now being followed up for cervical cancer treatment, to keep on living their lives.

\section{Final remarks}

The life stories portrayed transport us to the reality of life of elderly women and reveal they do not differ from the reality for this public in the country. The illness process occurs in view of the numerous absences of the State over their lives.

It is necessary more dialogue, to build collective actions that might know who these women are, as well as their fears and yearnings. We also highlight the need for a different look at elderly women, for in addition to the biological and physiological issues caused by the aging process, these women are the result of several social, historical and cultural determinations, which directly interfere in the way of understanding and handling life, going through their relationship with health. The intensive care for these women must consider their relationship with their bodies and their feelings in face of the meanings of the illness process and its consequences for their lives.

This research method allows the interviewer and, we risk telling the reader, to stand on the interviewee's behalf. It makes possible to approach a reality 
hegemonically discussed only based on numbers, but which, in this perspective, reveals the possibility of dealing with a wealth of senses and meanings. It also goes beyond the traditional and restricted idea about the concept of health, apprehending it in its correlation to various social determinants. ${ }^{1}$

\section{References}

ALBUQUERQUE, K. M. et al. Cobertura do teste de Papanicolau e fatores associados à não realização: um olhar sobre o Programa de Prevenção do Câncer do Colo do Útero em Pernambuco, Brasil. Caderno de Saúde Pública. Rio de Janeiro, v. 25, sup 2, p. S301-S309, 2009.

BANDEIRA, L. M. Violência de gênero: a construçáo de um campo teórico e de investigação. Revista Sociedade e Estado, v. 29, n. 2, maio-ago. 2014.

BELO, I. Velhice de mulher. In: COSTA, J. S. et al. (Eds.). Aproximaçôes e ensaios sobre a velhice. Franca, SP: UNESP, 2017. 210 p.

BRASIL. Ministério da Saúde. Controle dos cânceres do colo do útero e da mama. Brasília: MS, 2013 (Cadernos de Atenção Básica, n. 13).

CASTELLANOS, M. E. P. A narrativa nas pesquisas qualitativas em saúde. Ciência \& Saúde Coletiva, v. 19, n. 4, p. 1065-1076, 2014.

CISNE, M. Direitos humanos e violência contra as mulheres: uma luta contra a sociedade patriarcal-racista-capitalista. Serv. Soc. Rev. Londrina, v. 18, n. 1, p. 138-154, jul-dez. 2015.

COSTA, C. C. et al. Realização de exames de prevenção do câncer cérvico-uterino: promovendo saúde em instituição asilar. Revista Rene. Fortaleza, v. 11, n. 3, p. 27-35, 2010.

DATASUS. Indicadores e dados básicos. Brasil, 2012. Disponível em: < http://tabnet.datasus.gov. br/cgi/deftohtm.exe?idb2012/c10.def>. Acesso em: jun. 2015.

DEBERT, G.; BRIGEIRO, M. Fronteiras de gênero e a sexualidade na velhice. Revista Brasileira de Ciências Sociais, v. 27, n. 80, out. 2012.

DEBERT, G. G. Gênero e envelhecimento. Estudos Feministas, ano 2, n. 34, p. 34-51, 1994.

HADDAD, E. G. M. A ideologia da velhice. 2. ed. São Paulo: Cortez, 2017.

FEDERICI, S. Calibã e a Bruxa: mulheres, corpo e acumulação primitiva. Tradução do coletivo Sycorax, 2004. Disponível em <https:/edisciplinas.usp.br/pluginfile.php/4196118/ mod_resource/content/1/Federici\%2C\%20S.\%20\%282004\%29.\%20Caliba\%20e\%20a\%20 bruxa_mulheres\%2C\%20corpo\%20e\%20acumula\%C3\%A7\%C3\%A3o\%20primitiva.\%20 Cap\%C3\%ADtulo\%20IV.pdf> Acesso em: 15 out. 2019.

FERNANDES, J. V. Conhecimentos, atitudes e prática do exame de Papanicolaou por mulheres, Nordeste do Brasil. Revista de Saúde Pública, v. 43, n. 5, p. 851-858, 2009. 
FLORIANO, M. I.; ARAÚJO, C. S. A.; RIBEIRO, M. A. Conhecimento sobre fatores de risco associados ao câncer do colo uterino em idosas de Umuarama-PR. Arquivos de Ciência e Saúde Unipar. Umuarama, v. 11, n. 3, p. 199-203, 2007.

GOMES, R. et al. Gênero, direitos sexuais e suas implicações na saúde. Ciência \& Saúde Coletiva, v. 23, n. 6, p. 1997-2005, 2018.

HEILBORN, M. L. Entre as tramas da sexualidade brasileira. Estudos Feministas. Florianópolis, v. 14, n. 1, p. 336, jan-abr. 2006.

HENNING, C. E.; DEBERT, G. G. Velhice, gênero e sexualidade: revisando debates e apresentando tendências contemporâneas. Estudos sobre Envelhecimento, v. 26, n. 63, dez. 2015.

HOSPITAL DO CÂNCER DE PERNAMBUCO. Disponível em: <http://www.hcp.org.br/ index.php/institucional/apresentacao> Acesso em: 27 set. 2015.

INSTITUTO NACIONAL DE CÂNCER. Conhecendo o Viva Mulher. Programa Nacional de Controle do Câncer do Colo do Útero e de Mama. Rio de Janeiro: INCA, 2001.

- Coordenação Geral de Ações Estratégicas. Divisão de Apoio à Rede de Atenção Oncológica. Diretrizes para o rastreamento do câncer do colo do útero. Rio de Janeiro: INCA, 2011.

KULLOK, A. T. A força e o vigor da mulher idosa rural. Estudo Etnográfico sobre Envelhecimento em Dom Modesto, Caratinga-MG. Tese (Doutorado em Ciências) - 2012. Fundação Oswaldo Cruz. Rio de Janeiro, 2012.

MARANGONI, S. R.; OLIVEIRA, M. L. F. Uso de crack por multípara em vulnerabilidade social: história de vida. Revista Ciência Cuidado e Saúde, v. 11n. n. 1, p. 166-172, jan-mar, 2012. MINAYO, M. C. S. Pesquisa social: teoria, método e criatividade. In: - Ciência, técnica e arte: o desafio de pesquisa social. Petrópolis: Vozes, 2002.

NASRI, F. O envelhecimento populacional no Brasil. Revista Einstein, São Paulo, s. 1, p. 4-6, 2008.

PAIVA, S. O. C. Envelhecimento, saúde e trabalho no tempo do capital. São Paulo: Cortez Editora, 2014.

PASSAMANI, G. "É ajuda, não é prostituição". Sexualidade, envelhecimento e afeto entre pessoas com condutas homossexuais no Pantanal de Mato Grosso do Sul. Cadernos Pagu, v. 51, p. e175109, 2017.

PERES, M. A. C. Velhice e analfabetismo, uma relação paradoxal: a exclusão educacional em contextos rurais da Região Nordeste. Revista Sociedade e Estado, v. 26, n. 3, set-dez. 2010.

ROCHA-COUTINHO, M. L. A narrativa oral, a análise de discurso e os estudos de gênero. Estudos de Psicologia, v. 11, n. 1, p. 65-69, 2006. 
SANTOS, D. L. P. Análise do Sistema de Informação do Câncer do Colo Uterino em Pernambuco: 2007 a 2009. Dissertação (Mestrado em Saúde Coletiva) - Universidade Federal de Pernambuco, Recife, 2011.

SANTOS, A. M. R. et al. Câncer de colo uterino: conhecimento e comportamento de mulheres para prevenção. Revista Brasileira de Promoçáo da Saúde. Fortaleza, v. 28, n. 2, p. 153-159, abr-jun., 2015.

SANTOS, S. M. M.; OLIVEIRA, L. Igualdade nas relaçóes de gênero na sociedade do capital: limites, contradiçôes e avanços. Rev. Katál. Florianópolis, v. 13, n. 1, p. 11-19 jan-jun. 2010.

SILVA, A. P. et al. "Conte-me sua história": reflexôes sobre o método de História de Vida. Mosaico: estudos em psicologia. Belo Horizonte, v. 1, n. 1, p. 25-35, 2007.

SILVA, K. B. et al. Integralidade no cuidado ao câncer do colo do útero: avaliação do acesso. Revista de Saúde Pública, v. 48, n. 2, p. 240-248, 2014.

SILVA, D. M. G. V.; TRENTINI, M. Narrativas como técnica de pesquisa em Enfermagem. Revista Latino-Americana de Enfermagem, v. 10, n. 3, p. 423-432, maio-jun. 2002

VILLA, M. C. E.; PEREIRA, W. R. As políticas públicas e a atenção ao câncer do colo do útero no Estado de Mato Grosso - uma abordagem crítica. Revista Eletrônica de Enfermagem, v. 11, n. 4, p. 1037-42, 2009.

VILAÇA, M. N. Diferenças nos padrôes de tratamento e nas características epidemiológicas entre pacientes idosas e adultas portadores de câncer do colo do útero. Revista Brasileira de Cancerologia, v. 58, n. 3, p. 497-505, 2012.

TEIXEIRA, S. M. Envelhecimento e trabalho no tempo do capital: implicaçóes para a proteção social no Brasil. São Paulo: Cortez, 2008.

\section{Note}

${ }^{1}$ N. M. Costa: conception and design of the study, data collection and analysis, writing of the article. A. F. B. Bezerra and K. S. de B. e Silva: conception and design of the study, data analysis, critical review of the article. 


\section{Resumo}

\section{Histórias de vida de mulheres idosas com câncer de colo do útero: um olhar para além do adoecer}

As doenças crônico-degenerativas assumem grande predominância no perfil epidemiológico, acometendo a população idosa. Entre essas doenças, o câncer tem sido estudado, ampliando as informaçóes e trazendo avanço científico no cuidado à doença, contudo, as publicaçôes constantemente centram-se nos dados estatísticos, deixando de lado a história de vida dessa população. O presente artigo objetivou compreender a relaçáo com o processo de adoecimento de mulheres idosas em seguimento para o câncer do colo do útero, por meio da aproximação com as suas histórias de vida. Trata-se de um estudo qualitativo, cujo método utilizado foi o da história de vida. A escolha metodológica visou proporcionar um encontro com a vida de diferentes mulheres, dando visibilidade às suas memórias. Participaram da pesquisa cinco mulheres idosas com idade entre 62-89 anos, resultando em diferentes histórias de vida, com suas singularidades, mas que se entremeiam diante da dura realidade enfrentada por elas ao longo de seu processo de envelhecimento. A relação delas com o processo de adoecimento é permeada pelo medo em diferentes dimensôes. Conclui-se que há necessidade de um olhar diferenciado para a mulher idosa, considerando as relaçôes sociais que interferem no curso de sua vida e determinam a sua velhice.

> Palavras-chave: idoso; mulher; neoplasias do colo do útero. 